\title{
MULTIKULTURALISME DESA DI BALI DALAM KONTROL NEGARA: IMPLEMENTASI DANA DESA BAGI KEGIATAN LINTAS BUDAYA DI BADUNG DAN BULELENG
}

\author{
Piers Andreas Noak ${ }^{1}$, I Ketut Putra Erawan² \\ ${ }^{1}$ Fakultas Ilmu Sosial dan Ilmu Politik, Universitas Udayana \\ email: andreas.noak@unud.ac.id \\ ${ }^{2}$ Fakultas Ilmu Sosial dan Ilmu Politik, Universitas Udayana \\ email: ketut.erawan@gmail.com
}

\begin{abstract}
This study examines the implementation of village funds related to the development of crosscultural activities in Badung and Buleleng. Whether the pattern is instructive translation of sloganitic deconcentration tasks or participatory institutionalization that sets out the need for cross-cultural issues in the village. The Tamatea Study (2006), Parker (2017), and Gottowick (2010) discuss multiculturalism as the nature of local wisdom which is described as responding to people's daily problems. Another study, Kwon (2018) and Selenica (2018) looked at multiculturalism in the perspective of intercultural conflict. This research takes a different position from previous research by criticizing the construction of state control over multiculturalism that runs at the grassroots. Control construction is seen from the management of village funds for cross-cultural activities that are operationalized through guaranteed equality of ethnic and religious groups. The research paradigm is non-positive with case studies. Data collection methods utilize observation, interviews and documentation. The perspective used is interpretive with the theory of discourse. Research results show that state control is firmly embedded in the development of multiculturalism in villages. The nature of control is meaningfully driven, administrative control of budgeting has the potential to have an inhibiting effect on the development of the potential of the village concerned, including the development of multiculturalism activities in the village. Such as overlapping regulations on financial accountability, lack of socialization of regulations and assume that village human resources have understood every multicultural development program (especially the deconcentration program), injustice attitude views the potential of the village and bias behavior rules that are biased. Various attitudes are often shown by vertical government officials, such as sub-districts, offices (OPD), and ministries, which are counterproductive to oversee the development of the attitude of the development of multiculturalism in the village. Villages are forced to translate multicultural development programs that are trapped in administrative accountability which in reality compartmentalize the potential of the resources within.
\end{abstract}

Keyword: control; budget; multiculralism; state.

\begin{abstract}
ABSTRAK
Penelitian ini mengkaji implementasi dana desa terkait pengembangan kegiatan lintas budaya di Badung dan Buleleng. Apakah polanya instruktif penerjamahan tugas dekonsentrasi yang sloganitik atau pelembagaan partisipatif yang berangkat kebutuhan persoalan kelintasbudayaan di desa. Studi Tamatea (2006), Parker (2017), dan Gottowick (2010) membahas multikulturalisme sebagai kodrat kearifan lokal yang dideskripsikan
\end{abstract}


"serba bisa" menjawab persoalan keseharian warga. Studi lain, Kwon (2018) dan Selenica (2018) melihat multikulturalisme dalam perspektif konflik antar budaya. Riset ini mengambil posisi berbeda riset sebelumnya dengan mengkritisi konstruksi kontrol negara atas multikulturalisme yang berjalan di akar rumput. Konstruksi kontrol dilihat dari pengelolaan dana desa bagi kegiatan lintas budaya yang dioperasionalisasi lewat jaminan kesetaraan kelompok suku dan agama. Paradigma riset ini non positifis dengan studi kasus. Metode koleksi data memanfaatkan observasi, wawancara dan dokumentasi. Perspektif yang digunakan interpretatif dengan teori wacana. Hasil riset menunjukan kontrol negara masih tertanam kuat dalam pembangunan multikultiralisme di desa. Sifat kontrol bermakna driven, kontrol administratif penganggaran berpeluang memberi dampak penghambat bagi pengembangan potensi desa bersangkutan, termasuk pengembangan kegiatan multikulturalisme di desa. Seperti regulasi pertanggungjawaban keuangan tumpang tindih, ketiadaan sosialisasi aturan dan menganggap SDM perangkat desa sudah memahami setiap program pengembangan kegiatan multikultralisme (terutama program dekonsentrasi), sikap ketidakadilan memandang potensi desa dan perilaku bias aturan yang berat sebelah. Beragam sikap kerap ditunjukkan perangkat pemerintah vertikal, seperti kecamatan, dinas (OPD), maupun kementerian, yang kontraproduktif mengawal pengembangan sikap pegembangan multikulturalisme di desa. Desa dipaksa menerjemahkan program pembangunan multikultralisme yang terjebak pada pertanggungjawaban administratif yang realitasnya mengkotak kotakan potensi sumber daya didalamnya.

Kata Kunci: anggaran; desa; kontrol multikulturalisme; negara.

\section{PENDAHULUAN}

Bali adalah benteng pemeliharaan multikulturalisme yang ideal (Pickard, 1990). Konteks pemahaman ini dibangun atas penerjemahan berjalannya filosofi Tri Hita Karana. Filosofi yang menempatkan hubungan manusia dengan Tuhan, sesama, serta lingkungan sekaligus dasar relasi budaya Bali dengan budaya lain yang harmonis. Pada beberapa desa di Bali, harmoni ini berjalan ratusan tahun, bahkan kehadirannya mendahului eksistensi negara-bangsa. Setelah negara modern hadir, Bali dengan segala atribut kepariwisataan, menjelaskan kuatnya karakter kehadiran Negara lewat beragam kepentingan. Negara dan instrumen regulasi, seperti UU Desa, menjadi penjelas betapa pilar penyangga desa termasuk berjalannya multikulturalisme diatur sedemikian rupa oleh Negara. Menurut teori kedaulatan, negara memanifestasikan kedaulatan dalam instrumen penganggaran rutin desa sekaligus menegaskan kepemilikan kontrol berjalannya multikulturalisme dalam bingkai NKRI.

Multikulutralisme menjamin diversitas budaya yang didalamnya terdapat kesetaraan warga di arena publik (al-Makassary, 2007). Pada diversitas ini senantiasa memberikan peluang tumbuhnya ruang bersama (public sphere). Masyarakat multi budaya ditandai etnis beragam dan terdiri dari pola nilai baik sistem kepercayaan, ideologi, atau simbol kogintif (Ardhana, 2011:15). Multi budaya dioperasionalisasikan pada praktik jaminan kesetaraan partikularitas kelompok suku dan agama yang dikonstruksi sistem ide atau pengetahuan masyarakat setempat (Goodenough, 1967, Ahimsa-Putra, 2007, Gutomo, 2008).

Manifestasi negara dalam UU Desa dan berjalannya iklim multikulturalisme perlu membutuhkan kajian mendalam. Hal ini terutama anggaran desa sebagai aktualisasi UU desa memiliki idealisasi kepublikan. Idealisasi yang menyertakan pilihan demokrasi deliberatif dengan pelibatan pemangku kepentingan, atau sekedar menerjemahkan kepentingan parsial elit lokal sehingga resisten konflik. Beberapa kasus mengemuka pemanfaatan anggaran desa bias elit. Alasan yang mendasari, minimnya pengetahuan 
perangkat desa (Noak, 2016) hingga ketakutan kasus korupsi yang memaksa mereka mengambil jalan aman replikasi program pemerintah pusat, padahal alokasi tahun 2019 mengalami kenaikan (Kompas, 5 Juli 2018).

Riset ini mengkaji problematika mekanisme penganggaran dana desa yang menjamin berjalannya pemeliharaan multikulturalisme di desa. Apakah kontrol negara melalui pemberlakukan regulasi desa justru menemukan hakikat yang diidealkan atau justru kontraproduktif dengan menyimpan resistensi konflik akibat ketidakmampuan merespon problematika spesifik terkait multikulturalisme di level lokal.

Berdasarkan latar belakang, riset ini menelisik pola pemanfaatan dana desa bagi pengembangan kegiatan lintas budaya. Lintas budaya pada riset ini diarahkan sebagai praktik jaminan kesetaraan partikularitas kelompok suku dan agama yang dikonstruksi sistem ide atau pengetahuan masyarakat. Pertanyaan dijabarkan pada pertanyaan, bagaimana proses penyusunan perencanaan penganggaran, implementasi, hingga monitoring evaluasi kegiatan lintas budaya (mengakomodasi kesetaraan suku atau agama) yang teranggarkan dari pos dana desa di Desa Dalung, Badung dan Desa Pegayaman, Buleleng? Apakah polanya instruktif atau partisipatif? Instruktif dalam takaran proses siklus penganggaran dana desa hanya sekedar penerjamahan tugas dekonsentrasi yang sloganistik; atau partisipatif yang benar-benar melembagakan kebutuhan persoalan kelintasbudayaan wilayah desa bersangkutan.

Jawaban atas pertanyaan dianalisis dengan analisa yang menghubungan setiap pernyataan dengan realitas struktur makro yaitu bagaimana negara mengkonstruksi upaya kontrolnya atas harmoni multikulturalisme yang berjalan melalui proses penggangaran pada level akar rumput yaitu desa. Jadi uraian jawaban rumusan masalah tidak sekedar dideskripsikan secara mekanistik normatif, melainkan dianalisis secara kritis sehingga penelitian mampu mendiagnosa alasan penghambat dan pendorongnya secara komprehensif.

\section{TINJAUAN PUSTAKA}

Selama ini riset terkait praktik multikultralisme sudah cukup banyak. Seperti kajian-kajian yang dilakukan Pageh, dkk (2014). Sebagian besar kajian membahas topik multikulturalisme terkait proses historis maupun bentuk praktek toleransi antar budaya yang dioperasionalisasikan sebagai aktifitas lintas agama atau kepercayaan sebagai deskripsi unsur kearifan lokal setempat.

Riset Pageh menuliskan pemahaman latar belakang sejarah Enclave Nyama BaliNyama Selam di Bali dengan menganalisis faktor integratif keduanya dalam kerangka pengembangan kerukunan antarumat beragama di Bali. Dengan metode sejarah, riset ini menggunakan koleksi data etnografi, baik penentuan informan sampai analisis data. Hasil riset menunjukkan latar belakang sejarah kearifan enclave Nyama Bali-Nyama Selam, berkaitan dengan integrasi dan harmoni sosial di era otonomi daerah yang realitasnya juga tidak dapat dilepaskan dari sejarah masuknya agama Islam ke Bali terkait perdagangan di pinggir pantai. Hal ini seperti Islam di pinggir pelabuhan Buleleng, Sangsit, Temukus kemudian menyebar ke pedalaman bertani seperti Islam di Pancasari, Tegalinggah, dan Batu Gambir di pedalaman Karangasem.

Kajian lain terkait multikulturalisme dibahas pula pada penelitian Ardhana, Soenaryo, Sulanjari, Suwitha, dan Gde Putra (2011). Penelitian hibah strategis nasional ini membahas karakter multibudaya masyarakat Bali yang terbentuk dari proses migrasi berbagai kelompok etnis ke berbagai wilayah. Mereka memiliki peran politik, ekonomi, budaya, dan diaspora berbagai kelompok etnik namun tetap memiliki ikatan budaya yang kuat dengan daerah asal. Penelitian yang dibukukan dalam Masyarakat Multikultural Bali 
ini mendeskripsikan proses terbentuknya masyarakat multikultural di Bali serta nilai-nilai budaya dalam kaitan ikatan kekerabatan kelompok etnis yang ada. Beberapa definisi serta temuan penelitian pada buku ini akan dimanfaatkan sebagai panduan pada riset ini.

Hanya saja kajian terkait praktik multikulturalisme sebagai implikasi diberlakukannya Undang Undang Desa jumlahnya masih minim. Multikulturalisme dipandang sebagai cara pandang multibudaya yang mengandung kejamakan sistem ide. Multikulutralisme menjamin diversitas budaya yang didalamnya terdapat kesetaraan warga pada arena publik (al-Makassary, 2007). Pada sistem ide ini, diversifitas memberikan peluang tumbuhnya ruang bersama atau public sphere. Multi budaya teroperasionalisasi melalui praktik jaminan kesetaraan partikularitas kelompok suku dan agama dimana dikonstruksi oleh sistem ide atau pengetahuan masyarakat (Goodenough, 1967, Ahimsa-Putra, 2007, Gutomo, 2008).

Beberapa kajian internasional terdahulu yang memiliki relevansi riset ini diantaranya kajian Tamatea (2006), Parker (2017), dan Gottowick (2010). Tulisan Gottowick mendeskripsikan bagaimana kebudayaan yang muncul di Bali merupakan realitas perpaduan beragam budaya. Menurut orang Hindu-Bali, leluhur mereka berasal dari Jawa, agama mereka dari India, dan beberapa ciri budaya mereka dari Cina. Mereka melihat asal usul diri sekaligus akar agama dari pengaruh budaya di luar pulau mereka. Beberapa praktik atas deskripsi ini diambil Gottowick melalui aktualisasi budaya Barong Landung.

Tokoh Barong Landung mengartikulasikan dimensi perpaduan budaya yang tercermin pada mitos, legenda, lagu, dan dialog. Beberapa kekhasan perpaduan budaya ini membentuk orientasi ruang baru. Konsep trans-lokaliti dan trans-kulturaliti diekspresikan pada tingkat simbolik melalui bentukan budaya Barong Landung. Pencermatan Barong Landung sebagai hasil proses transfer global dan pertukaran lintas budaya akhirnya menjadi harmoni berjalannya multikulturalisme di tingkat lokal. Masyarakat mengambil bentuk baru, atau yang disebut transkultural, bahkan melewati batas-batas budaya klasik mereka. Ekspresi budaya Hindu-Bali juga disimboliskan dengan perkawinan Putri Cina dan Raja Bali, dimana karakter perbedaan ini dilukiskan pada tempat pernikahan, kisah migrasi suami dan pengantin wanita termasuk simbol yang mengatasi batas-batas budaya berbeda.

Pada tulisannya Gottowick mengutip Welsch bahwa multikulturalitas antarbudaya mengabaikan fakta otonomisasi atas budaya itu sendiri melainkan mengarah pada keragaman bentuk baru. Gagasan ini diekspresikan dengan jelas dalam narasi Hindu-Bali seperti perkawinan campuran dari dua orang yang berbeda dianggap tidak menghasilkan budaya yang seragam atau homogen melainkan yang baru, yaitu budaya Bali. Limitasi tulisan ini tidak mengeksplorasi bagaiamana proses multikulturalisme saat berhadapan dengan kekuatan dominasi kuasa baru yaitu Negara. Negara dengan kulturnya yang disebut rejim tata kelola kerap memberikan warna perbauran atau pertautan antar budaya.

Penelitian lain, dilakukan Tamatea yang mencermati pembumian multikulturalisme di Bali dalam dunia pendidikan pasca Bom Bali tahun 2003. Tamaeta melakukan riset studi kasus di salah satu yayasan sekolah di Bali dengan koleksi data etnografi berupa observasi dan wawancara. Pada temuannya ia mengungkapkan sekolah di Bali memiliki paduan nilai lokal yang berangkat dari model pendidikan dasar Gandhi (Nai Talim). Model pendidikan ini pengejawantahan ajaran Ahimsa, menitikberatkan toleransi dan kedamaian dipadu dengan model wacana globalisasi dimana diterapkan bersama pada kurikulum sekolah lokal setempat.

Model Nai Talim menekankan pemanfaatan unsur media pengajaran yang tepat, melakukan pengajaran sesuai panggilan, adaptif perkembangan teknologi serta mengedepankan/mengutamakan toleransi. Hanya saja, temuan Tamatea mengungkapkan 
bahwa pembumian multikulturalisme pada kurikulum sifatnya menyertakan beragam wacana/diskursus.

Globalisasi membuka ruang artikulasi dengan pasar neo liberalistik yang justru menjadi tantangan terbesar dalam mempertahankan nilai multikulturalisme tetap berjalan. Kepentingan ekonomi kapitalistik yang tercipta dari pasar neo liberal seringkali menggeser kepentingan nilai lokal yang sebenarnya menjadi elemen penting pemeliharaan toleransi dan perdamaian. Limitasi tulisan tidak eksplisit mengungkapkan bagaimana saat nilai multikulturalisme lokal berhadapan dengan intrumentasi negara berupa regulasi, serta tidak mendeskripsikan detail pertarungan atau negosiasi penyesuaian kurikulum konten lokal dengan nilai global yang tentu memiliki kepentingan sendiri. Limitasi ini justru menjadi bahasan pada riset ini.

Studi lain tulisan Parker yang menjelaskan pengalaman siswa perempuan muslim pada sekolah menengah di Bali, mengingat agama mayoritas di Bali adalah Hindu Bali. Praktek multikulturalisme mengenai pemakaian jilbab masih memiliki dinamisasi persepsional. Dengan teknik wawancara kepada siswi, guru dan orang tua di sekolah menengah atas negeri maupun swasta di Denpasar menyatakan pengenaan jilbab sebagai benteng moralitas dianggap aman baik secara lingkungan maupun agama. Namun beberapa orang berpendapat bahwa mengenakan jilbab di sekolah sehari-hari menemui dinamika tersendiri, seperti pola relasi dengan sekolah, guru dan teman sepergaulan. Ini dianggap penulis sebagai sekat pembatas multikulturalisme di Bali.

Beberapa perempuan muslim menginternalisasi dinamisasi terhadap wacana yang berkembang atas dirinya, juga persepsi penandaan status mereka yang tidak sama dialami pria muslim minoritas. Limitasi artikel Parker tidak menjelaskan bagaimana pengaruh perbedaan persepsional kalangan minoritas terhadap berjalannya harmoni multikulturalisme di tingkat lokal. Selian itu, Parker tidak mendeskripsikan peran negara melalui instrumen yang dibentuk melalui otorisasi regulasi mengatur kewenangan atas posisioning minoritas ditengah masyarakat mayoritas. Limitasi ini menjadi perhatian kajian dalam studi ini.

Multikulturalisme sebagai instrumentasi pereda konflik, dituliskan Kwon (2018) dan Selenica (2018). Tulisan Kwon menuliskan peran kebijakan multikultural terutama penanganan masalah sosial. Wacana kebijakan multikulturalisme selama ini dikembangkan dalam bentuk fasilitasi kalangan marginal agar diakui sebagai warga negara nasional kebanyakan. Multikulturalisme adalah persoalan memediasi kalangan marginal atau migran dengan penduduk asli. Meski kebijakan multikultural seringkali yang didorong adalah integrasi etnis. Hanya saja realitasnya, para kritikus berpendapat bahwa imigran cenderung enggan berasimilasi dan selalu mengalami perpecahan budaya karena tidak beradaptasi dengan nilai arus utama. Salah satu isu kebijakan terkait multikultural yang paling bisa diterima adalah kebijakan sosial seperti pengaturan tempat tinggal dan sikap pilihan orientasi seksualitas imigran kelompok. Berangkat dari realitas ini, kebijakan multikulturalis justru memfasilitasi adanya sifat negatif.

Senada pula tulisan Selenica yang menekankan pendidikan sebagai sarana rekonsiliasi konflik pada negara yang memiliki latar belakang pasca-perang periode 19992014. Riset ini mengidentifikasi titik temu historis antara ide yang bersaing dengan aktor negara yang bermunculan periode pasca-perang khususnya pada pendalaman visi pendidikan.

Analisisnya menunjukkan peran pendidikan di Kosovo pasca-perang mencerminkan ketegangan antara upaya perwujudan multikulturalisme yang dipromosikan aktor internasional berhadapan dengan aktor nasionalis. Hal yang sering menjadi keprihatinan adalah rekonsialisasi bidang pendidikan yang terbentur dengan 
kecenderungan orang berusaha menuntut haknya yang setara, atau otonomi luas pada berbagai komunitas sehingga kerapkali menyulitkan terwujudnya berjalannya harmoni multikulturalisme pada negara bersangkutan. Kedua kajian ini mengalami keterbatasan, yaitu tidak mendeskripsikan multikulturalisme sebagai strategi membangun konsiliasi ragam kekuatan dari dalam sekaligus menjelaskan bagaimana pertarungan budaya yang ada pada masyarakat termasuk pemaknaannya terhadap berjalannya kontrol negara.

Limitasi penelitian diatas akan menjadi bahasan riset ini dengan mengakomodasi operasionalisasi konsep penelitian-penelitian tersebut. Seperti, pengaruh trans-lokaliti dan trans-kulturaliti serta bentuk pengkompromiannya pada proses penganggaran dana desa terkait multikultralisme (Gottowick, 2010). Potensi resiko prioritas penganggaran publik terkait kegiatan multikulturalisme yang terdominasi kepentingan pengembangan ekonomi pasar (Tamatea, 2006). Tingkat persepsional kelompok suku atau agama minoritas serta sebaliknya pada penganggaran dana desa terkait multikulturalisme (Parker, 2017). Solusi terkait proses ini juga dikembangkan pada model fasilitasi kebijakan sosial yang mengakomodasi kelompok suku atau agama minoritas oleh kelompok suku atau agama mayoritas dalam proses penganggaran publik (Kwon, 2018). Identifikasi kelompok maupun aktor yang memfasilitasi kompromitas mayoritas dan minoritas kelompok suku/agama dalam proses penganggaran dana desa terkait kegiatan multikulturalisme (selenica, 2018).

Untuk menjawab keterbatasan riset pendahuluan yang sudah ada, maka penelitian akan menggunakan analisis teori wacana yang dikemukakan Laclau dan Moeffe. Pada teori wacana ini, pihak yang terlibat dalam perencanaan, implementasi hingga monitoring evaluasi saling mengartikulasikan makna multikulturalisme menuju diskursus nodal points melalui konsep hegemoni. Pada pengartikulasian ini, terdapat power struggle dalam pembentukan diskursus multikulturalisme yang teraktualisasi dalam pemanfaatan anggaran publik di desa.

Pemahamannya, makna multikulturalisme adalah empty signifier atau penanda kosong dan tidak dapat diinderakan (sebagai matter). Multikulturalisme adalah bentukan penginderaan atas matter, seperti "kompromi", "toleransi", "penggabungan dua suku atau agama" atau "usaha peradamaian". Berdasarkan pada penginderaan inilah maka multikulturalisme saat dihadapakan dengan fungsi praktis penganggaran desa diyakini oleh banyak bentuk elemen makna yang berada di luar dirinya, termasuk realitas sosial yang ada disekelilingnya. Penanda kosong merujuk hal ideas dan bukan matter dimana tidak dapat diinderakan sehingga akan muncul banyak pemaknaan terhadap keberadaan multikultralisme yang berupa signified atau pertanda. Pertanda akan menjadi hegemoni saat pemaknaannya menjadi penanda kosong secara universal (Laclau, 2010:10).

Melalui bantuan teori wacana ini, maka akan diketahui persepsi dominan yang membentuk konstruksi narasi dominan masyarakat mengenai realitas, khususnya dalam riset ini adalah makna multikultralisme saat dihadapkan dengan instrumen regulasi desa. Hal ini juga akan dilihat bagaimana para pemangku kepentingan perencana, implementator dan pemonev anggaran desa mengkontruksi diskursus terkait multikulturalisme serta kontestasi identitas identitas yang menyertainya. Pemanfaatan dana desa terkait kegiatan lintas budaya tidak sekedar dideskripsikan secara mekanistik normatif, melainkan dianalisis kritis sehingga penelitian ini akan mampu mendiagnosa alasan penghambat dan pendorongnya secara komprehensif. 


\section{METODE}

Penelitian ini berjenis penelitian studi kasus. Penelitian ini menggunakan metode deskriptif kualitatif. Metode kualitatif mengikuti prosedur penelitian yang menghasilkan data deskriptif, yaitu berupa kata-kata tertulis dari perilaku yang diamati (Moleong, 2005:16). Penelitian ini diarahkan pada penggambaran obyek penelitian secara holistik (menyeluruh). Untuk memperoleh data secara holistik, maka teknik pengumpulan data dari penelitian ini adalah melalui teknik koleksi data observasi adalah teknik pengataman secara komprehensif peristiwa atau realitas yang terjadi di seputar obyek riset. Teknik koleksi data wawancara adalah teknik pengumpulan data melalui tanya jawab secara langsung dimana pihak penanya (interviewer) berhadapan langsung secara fisik dengan pihak yang ditanyai (interviewee). Metode wawancara yang digunakan pada penelitian ini adalah metode wawancara mendalam (in-depth interview) dengan berpedoman pada daftar wawancara yang sudah dibuat / dipersiapkan sebelumnya (interview guide). Wawancara mendalam pada suatu penelitian bertujuan menghimpun keterangan tentang fenomena dalam masyarakat (Melly, 1994:129). Penggunaan teknik wawancara ini dimaksudkan mendapatkan data primer mengenai makna multikulturalisme dalam penyusunan penganggaran publik desa di Bali. Teknik dokumentasi yaitu kegiatan melakukan analisis terhadap dokumen-dokumen atau data tertulis yang berhubungan dengan penelitian ini.

Lokasi penelitian dilakukan pada dua desa yaitu Desa Dalung, kabupaten Badung dan Desa Pegayaman, Kabupaten Buleleng, Kedua desa ini dianggap sebagai representasi atas heteregonitas penduduk dan realitas masyarakatnya berada dalam sistem nilai budaya yang berbeda. Desa Pegayaman, Kecamatan Sukasada, Kabupaten Buleleng adalah desa dengan mayoritas penduduk muslim. Sedangkan Desa Dalung, Kecamatan Kuta Utara, Kabupaten Badung merupakan desa dengan mayoritas penduduk Hindu namun terdapat pula yang beragama Non Hindu, yaitu muslim dan kristiani.

Teknik penentuan informan dilakukan secara purposive sampling, yaitu mereka dipandang memiliki pengetahuan sesuai dengan topik penelitian. Pada teknik ini, peneliti mewawancarai beberapa narasumber kunci terlebih dahulu di tingkat Pemerintah Kabupaten, yaitu dinas atau badan pengkoordinasi penyelenggara pemerintahan desa termasuk pemerintah kecamatan setempat. Kemudian teknik koleksi data berupa wawancara dilanjutkan ke perbekel desa lokasi penelitian, yaitu perbekel desa dan perbekel desa...Pada narasumber ini, melalui teknik snow ball diharapkan akan didapatkan informasi kunci yang sangat penting terkait responden penelitian yang akan diwawancarai, termasuk para pemangku kepentingan yang terlibat langsung dalam perencanaan, implementasi maupun monitoring evaluasi penganggaran publik desa terkait dengan kegiatan lintas budaya.

Pada proses ini dilakukan klasifikasi berdasarkan ikatan kesukuan, agama, umur, pekerjaan, jenis kelamin, dan penghasilan (Callahan, 2005). Data-data yang dikumpulkan kemudian diterjemahkan dalam bentuk transkripsi hasil wawancara. Hasil transkrip wawancara ini dipilah dan dikategorisasi sesuai dengan kebutuhan penelitian. Penyajian penelitian ini dilakukan dengan cara menggabungkan pengolahan data yang diperoleh dari hasil interview informan serta dokumentasi yang diperoleh, baik yang maupun informasi dari media pendukung lainnya (buku, internet, dll).

\section{HASIL DAN PEMBAHASAN}

Berdasarkan data lapangan, hambatan terbesar dalam proses pengelolaan keuangan di tingkat desa lebih banyak bersumber pada ketidaksinkronan aturan main program-program dekonsentrasi yang dimiliki oleh instansi vertikal dengan pemerintah desa. Desa maunya praktis, namun seringkali pemerintah vertikal, misalnya kecamatan, justru memiliki perangkat aturan tersendiri yang tidak tersosialisasikan cukup baik di kalangan pelaksana. Akibatnya, seringkali eksekusi program kegiatan untuk langsung memberikan outcome pada kelompok sasaran menjadi terhambat. 
Pada salah satu kisah yang dituturkan informan riset ini bahwa hambatan ini pernah dijumpai dalam penyaluran beras sejahtera (Rastra) dimana pada akhirnya perangkat desa akhirnya harus mendapat tuduhan dugaan pungutan liar pembagian selama bulan Maret dan April 2018. Program ini adalah program dekonsentrasi Kementerian Sosial. Hakikat program pembagian beras ditujukan pada kelompok sasaran seluruh masyarakat keluarga miskin di wilayah Pegayaman dengan sifatnya yang lintas agama maupun kelompok (secara multikultur). Hanya saja, acuan terhadap pelaksanaan program ini mengacu pada peraturan dari pemerintah pusat, yaitu regulasi dari Kementrian Sosial Tahun 2017.

Beberapa arahan kementrian yang ditetapkan dalam regulasi tersebut bahwa Rastra dibagikan dengan jatah $10 \mathrm{~kg}$ per KK dan tak boleh kurang. Dalam pendistribusian, dilarang keras memungut uang dari penerima alias gratis. Hal inilah yang kemudian menjadi pangkal masalah yang pernah dialami oleh perangkat desa Pegayaman. Di satu sisi, untuk menyingkat mekanisme penyaluran program kepada kelompok penerima, perangkat desa bisa langsung mengalokasikan kepada kelompok sasaran. Berdasarkan hasil koordinasi perbekel dengan kelompok penerima, karena terdapat jarak warga penerima rastra letaknya jauh dari kantor kepala desa, mereka bersepakat untuk membayar ongkos transport pengiriman beras dari balai desa ke alamat penerima sesuai jarak dengan besaran bervariasi.

Warga Pegayaman kerap mengeluarkan uang untuk menyewa ojek hingga Rp 20 ribu mengingat kondisi jalan masih rusak dan jauh sehingga membuat sewa ojek cukup mahal dan membebani warga. Sebagai solusinya, warga bersepakat membayar ongkos transport lebih murah, dengan besaran bervariasi, mulai dari Rp 3 ribu-Rp 5 ribu. Perbekel mengklaim kalau solusi ini diambil secara kesepakatan dan langkah ini harus segera ditempuh karena dikhawatirkan beras menumpuk di Kantor Perbekel, sehingga mengganggu pelayanan masyarakat. Apalagi di kantor perbekel tak memiliki gudang penyimpanan beras. Rastra juga sudah dibagikan sesuai jumlah penerima yakni $590 \mathrm{KK}$ yang tersebar di lima banjar dinas yakni Banjar Dinas Barat Jalan 76 KK, Banjar Dinas Timur Jalan, 96 KK, Banjar Dinas Kubu 213 KK, Banjar Dinas Kubu Lebah 140 KK, Banjar Dinas Amertasari $94 \mathrm{KK}$. Hanya saja, seperti realitas yang terjadi di manapun, apabila si penerima seringkali memberikan lagi kepada kelompok warga lain yang kesusahan, seperti kerabatnya, hal ini adalah sesuatu yang sangat sulit dideteksi oleh perangkat desa setempat karena pelaksanaannya seringkali dilakukan di bawah tangan.

Hanya saja, di sisi lain, kesepakatan warga ini justru dianggap oleh instansi vertikal tidak ada koordinasi, terutama dari sisi instansi vertikalnya, baik dengan pihak Kecamatan atau Dinas Sosial Pemerintah Kabupaten. Hal ini disebut mereka "melabrak aturan" dan "berpotensi menjadi temuan". Termasuk pula solusi membagi rata jatah rastra kepada warga yang terdaftar di SK disebut menyalahi aturan. Hal ini karena penerima rastra sudah dibuatkan SK dari Kementrian Sosial dan tidak boleh dibagi kepada warga yang tidak terdaftar di SK. Kalau tindakan ini dilakukan dianggap menyeret instansi vertikal setempat dan berpotensi menjadi temuan. Bagi instansi vertikal, apabila pemerintah desa ingin menambah daftar calon penerima rastra bisa dilakukan di Musyawarah Desa, termasuk mengundang mereka, namun hanya bisa direalisasikan pada tahun mendatang. Instansi vertikal selalu berpegang pada aturan dan rambu rambu temuan dimana terkadang justru mengabaikan hakikat awal outcome pemberian program itu sendiri. 
Hal ini yang seringkali menjadi keluhan perangkat desa Pegayaman. Ungkapan instansi vertikal atas masalah ini, adalah sebagai berikut:

"Kalau ada warga yang tidak mau mengambil beras secara langsung ke kantor perbekel karena alasan jauh, ya tidak usah dibawakan ke rumahnya. Buat berita acara. Kok dikasi bantuan gak mau. Kembalikan berasnya ke negara. Selesai sudah, jangan sampai warga dikenakan biaya antar seperti ini, meskipun atas kesepakatan. Kalau tidak ingin berasnya numpuk di kantor perbekel ya kordinasi dengan kami. Akan kami berikan tenda" (Kutipan wawancara dari Bali Express tanggal 2 Mei 2018 diakses pada https://baliexpress.jawapos.com/read/2018/05/02/69890/soalrastra-pegayaman-disalahkan-dinsos-perbekel-ngotot-tak-salah, Minggu 22 September 2019).

Bagi pemerintah desa, Instansi vertikal dalam memberikan bantuan program terutama yang bersifat dekonsentrasi, seolah bias kosmetikal, hanya mengejar kepentingan perfomatikal yang bersifat rutinitas tanpa perhitungan cermat dan berkoodinasi dengan pihak desa terkait sebagai sasaran program. Seolah Desa merasa selalu siap saat diberikan bantuan, termasuk semua perangkat yang dianggap sudah paham semua akan rambu rambu pemberian bantuan meski tanpa harus disosialisasikan terlebih dahulu. Saat Pemerintah Desa mengeksekusi kebijakan atas dasar pelaporan dan kondisi bantuan, seringkali didominasi dengan sikap penyalahan instansi pemberi bantuan. Inilah yang dipersepsikan oleh perangkat desa, bahwa segala bentuk aturan dan program yang diterbitkan instansi vertikal seringkali tidak berangkat pada kondisi di lapangan dan sifatnya seringkali menghambat kinerja pemerintah desa.

Segala bentuk perencanaan kegiatan pembangunan, termasuk terkait dengan pembanguan multikultralisme, selalu didasarkan pada perencanaan yang diperoleh melalui musyawarah desa. Musyawarah ini diawali di tingkat dusun baru setelah selesai di lanjutkan di tingkat musyawarah desa. Pada musyawarah ini perangkat desa dan LPD mengklasifikasikan termasuk merangking skala prioritas. Hal ini karena dana terbatas dan dea Pegayaman tidak memiliki PAD. Perangkingan ini melibatkan tokoh informal dan tokoh formal desa, baru kemudian secara bertahap dikerjakan. Dalam penentuan skala prioritas ini juga disertakan volume yang disetimasikan mendekati kebutuhan agar nanti anggaran tidak menjadi sisa lebih anggaran (SILPA) karena akan menjadi sia sia.

Segala bentuk perencanaan pembangunan harus disesuaikan dengan RPJMDes selama enam tahunan dan kemudian diturunkan dalam RKT sebagai patokan penganggaran tahunan. Inilahyang menjadi dasar penyelenggaraan musyawarah desa dan kemudian khusus untuk pengerjaan fisik, akan menyepakati pelelangan selain penunjukan dengan prinsip tidak merugikan warga. Dasar dari kegiatan ini adalah mencari orang yang bisa dipercaya, terutama dalam penerimaan dan pemanfaatan barang. Segala bentuk pengembangan pembangunan termasuk di bidang multikulturalisme, sangat bergantung dari SDM. Asal SDM mengertia standar, maka semua akan bsia berjalan sesuai dengan yang diharapkan. Aspek koordinasi menjadi hal penting karena pada pratiknya, segala bentuk pembangunan selalu menemui kendala. Dalam penentuan pembangunan, perangkat desa tidak membedakan asal usul agama maupun tempat asal warga.

"Dari Jawa, Bali beragama Hindu atau Islam atau yang pro atau tidak pro dengan saya saat pemilihan, harus dikesampingkan. Prinsipnya pembangunan bisa berjalan baik di semua wilayah. Seperti pembangunan jalan di Pura Desa, karena prinsipnya akan memperbaiki sarana transportasi, semua prioritas ini bisa diterima semua 
pihak. Apabila transportasi baik maka kegiatan ekonomi akan meningkat sekaligus dapat mengurangi resiko kriminalitas. Jalan menuju kota dari desa akan lancar sehingga pembangunan inilah yang harus dikerjakan dan diprioritaskan. Pembangunan jalan menuju Pura Desa selama dua tahun berturt-turut diangarkan dengan tahun pertama di tahun 2018, sepanjang 1500 meter, dan di tahun anggaran 2019 sepanjang 1000 meter". (Wawancara Perbekel Desa Pegayaman).

Instansi vertikal, seperti kecamatan, maupun dinas seringkali tidak memahami kondisi lapangan di darahnya sendiri. Persoalan justru ada di mereka karena harusnya pihak instansi inilah yang harus punya rasa saling memahami dan mengerti atas kondisi yang ada di wilayahnya. Pada konteks yang dipahami informan riset ini, instansi vertikal ini selalu cenderung memaksa pendapat dengan mengatakan bahwa Desa A bagus dan Desa B harus seperti Desa A. Padahal konteksnya berbeda. Sesuatu yang bagus di satu wilayah, belum tentu bisa diterapkan di desa lainnya karena konteksnya berbeda. Konteks ini bisa sumber daya alam, sumber daya manusia ataupun pendapatan asli daerah yang berbeda. Pada kasus yang terjadi, desa Pegayaman selalu dibandingkan dengan kondisi wilayah di Git Git, yang notabene memiliki SDA sekaligus PAD cukup. Kalau pada satu sisi potensi sumber daya alam Git Git maju, namun kondisi yang diperbandingkan satu sama lain oleh perangkat instansi vertikal, seperti kecamatan atau kabupaten, menjadi sesutau yang bias dari keadilan. Hal ini karena bagaiamanapun kondisi alamnya sudah berbeda.

"Kami tidak punya SDA yang layak dijual maupun berkontribusi pada PAD. Namun sering pejabat instansi vertikal menuntut, namun apa yang dibicarakan hanya sebatas keinginan yang tidak menjajagi keadaan yang diajak berbicara. Kalau memang tidak punya PAD dan SDA bagaimana, masa harus dipaksa. Pejabat instansi vertikal atas sering menghina kita, kok tidak seperti desa ini atau itu. Jadi sesuatu yang dipandang baik, belum tentu baik bagi yang lain, karena masing masing tentu memiliki kultur berbeda beda". (Wawancara Perbekel Desa Pegayaman).

Pada setiap kegiatan yang memanfaatkan dana desa selalu diadakan tinjauan dan kunjungan agar realisasinya benar benar bisa menjawab kebutuhan warga di lapangan. Pada kegiatan pengembangan multikultur sepanjang perbaikan dan pembangunan sesuai koridor aturan maka itu akan dilakukan, seperti tempat ibadah milik desa, dan bukan milik perseorangan atau yayasan. Begitu pula lembaga pendidikan berdasarkan agama, sepanjang bukan punya yayasan dan milik desa seperti PKK maka akan diajukan di musyawarah desa untuk dijadikan prioritas sehingga akan diajukan untuk dibuat BKK untuk dibiayai.

Sumber dana desa ada dua jenis, yaitu bersumber dari dana APBN berupa dana desa (DD) dan besumber APBD Kabupaten masing masing berupa alokasi dana desa (ADD). Sebagai bagian dari program nasional, kedua desa dalam riset ini, yaitu Pegayaman dan Desa Dalung rata rata mendapatkan Dana Desa dari APBN yang relatif sama yaitu sebesar kurang lebih 3 Milyar pertahun. Sedangkan alokasi dana desa bersumber APBD besarannya variatif tergantung kemampuan masimg masing kabupaten.

Penggunaan dana desa bagi kegiatan pembangunan termasuk untuk pengembangan multikulturalisme disosialisasikan/diumumkan melalui baliho yang dipasang di tempat strategis. Mekanismenya untuk pengalokasian sumber dana ini, awalnya dilakukan melalui musyawarah dusun. Pada level ini musyawarah dilakukan guna menggali potensi di masing-masing dusun sekaligus mengetahui mana yang layak untuk didanai melalui DD atau ADD. Setelah dari dusun, kemudian usulan dibawa ke Musyawarah 
Desa. Setelah dimusyawarahkan akan dirangking di setiap dusun dan akan muncul, beberapa usulan.

Usulan ini digunakan untuk prioritas pembangunan yang masuk dalam dokumen RPJMDes. Setelah dituangkan dalam RPJMDes maka untuk penentuan anggaran setiap tahun ditentukan dalam musdes RKP. RPJMDes adalah siklus enam tahunan, sedangkan RKP adalah tahunan yang biasanya dilakukan pada bulan Juni. Setelah disetujui maka dengan dibantu tim pendamping desa akan membuat RAB. Disitulah akan muncul mana saja priorotas pembangunan yang perlu didanai. Tidak semua prioritas dikerjakan selama satu tahun anggaran berjalan namun bertahap. Misalnya ada lima usulan, maka usulan lain yang bukan prioritas akan dikerjakan pada tahun berikutnya sampai habis perencanaan di RPJMDes nya. Jadi pada intinya prioritas di dalam RPJM Des harus ada di RKP karena RKP adalah pengimplementasian atau pengeksekusiannya.

Dalam menentukan yang layak atau tidak layak didahulukan maka hal tersebut menjadi tugas tim verfikasi. Dalam musyawarah desa menyusun RPJM Des atau RKP selalu dihadiri perbekel, BPD, LPM, karang taruna, remaja masjid, PKK, subak dan semua kadus, serta unsur pendidikan. Pada musyawarah tersebut sekaligus ditentukan tim verifikasi. Tim verfifikasi ini berasal dari warga dengan memperhatikan keterwakilan satu orang dari setiap dusun yang ada di desa. Ketika memverifikasi tidak ada yang bisa saling mengintervensi. Anggotanya yetap kecuali kalau ada yang mengudnurkan diri. Dengan adanya tim ini maka ada aspek karena keterwakilan karena ada anggota yang menjadi duta bagi dusunnya, sekaligus merekalah ujung tombak yang menjelaskan capaian pembangunan pada warga di masing masing dusun.

Koridor terkait pengembangan kegiatan multikuturalisme harus milik desa. Misalnya sarana ibadah atau pendidikan harus milik desa ini. Kalau bukan milik desa maka tidak boleh didanai. Tempat ibadah milik desa dan tempat pendidikan bukan milik yayasan melainkan milik desa seperti dikelola PKK yang hanya meliputi PAUD atau TK. Untuk alokasi ADD kebanyakan untuk gaji aparat, kegiatan PKK, atau insentif kader dalam kegiatan pelatihan seperti pembuatan roti untuk pembiayaan pelatih dan alatnya.

Pada cerminan pembangunan multikuturalisme, prioritas yang muncul dalam pembangunan di dua tahun berjalan, tahun 2018-2019 adalah pembuatan jalan menuju Pura. Mengingat banyak pula yang beragama Hindu dan tempat peribatan mereka agak masuk, maka jalan dipandang perlu untuk diaspal karena kondisinya juga sudah hancur dimakan jaman. Karena Dana Desa memperbolehkan pembangunan fisik, maka prioritas ini direalisasikan. Relaisasi berupa betonisasi dengan memakan biaya 200 juta rupiah dan memperkanankan adanya swakelola, keterlibatan warga setempat baik Hindu maupun Islam untuk bekerja tanpa membedakan dan diupah. Begitu pula dengan kegiatan multikultralisme lain, pemerintah desa Pegayaman juga mendanai pengembangan grup samroh untuk pembelian alat musik dari ADD maupun DD. Begitu pula untuk Hindu, diuslkan pembiayaan sekaa gong. Hanya saja, disaat harmonisasi ini berjalan, terdapat pula kegiatan pengembangan yang beberapa diantaranya tidak bisa dibiayai karena hambatan pertanggungjawaban administratif. Seperti pembelian canangsari, yang notabene adalah unsur pelengkap penting upacar dalam Agama Hindu.

"Negara kurang bisa melihat keragaman kondisi di masing masing desa, termasuk desa adat, terutama kendala mereka pada masalah pertanggungjawaban penganggaran yang seringkali desa dinas akhirnya membantu atas beban mereka karena memang akibat keterbatasan kondisi SDM seperti penguasaan IT terutama pengerjaan excel keuangan". (Wawancara Sekretaris Desa Pegayaman). 
Negara melakukan kontrol terhadap segala bentuk pembangunan terutama dalam pengembangan multikulturalisme di level desa hanya kosmetikal. Yang ditampilan hanya penampilan luar bahwa mereka memberikan ruang kreatifitas bagi masing-masing desa, namun di sisi lain mereka masih memegang kendali yang sangat kuat terutama melalui kontrol pelaporan administrasi keuangan dengan beragam regulasi yang tumpang tindih. Hal ini seperti dituturkan oleh seorang informan:

"Kebijakan untuk membangun desa aturanya selalu berubah ubah. Kadang masih ada meja ini dan meja itu yang selalu tidak sama dan merepotkan. Misalnya soal setiap dana desa wajib kena pajak. Di tahun 2015 kami mengembalikan pajak sampai 25 juta rupiah. Karena pemahaman yang diberikan oleh Dinas PMD Kabupaten dan Kantor Pajak berbeda sama sekali. Dari Kantor Pajak dikatakan semua dana kena pajak, namun dari PMD, semua kegiatan kami tidak boleh kena pajak karena yang kena pajak hanyalah yang melibatkan transaksi dengan toko. Karena atasan kami adalah PMD, maka kami ikuti aturan mereka. Namun saat datang auditor, kami kena peringatan akibat perbedaan persepsi tersebut dan disuruh mengembalikan pajak. Ini perlu dituntaskan karena SDM di desa berbeda beda tidak semuanya sama, apalagi saat ini tuntutannya justru makin ketat dalam penguasaan teknologi seperti adanya pelaporan via sikudes" (Wawancara Sekretaris Desa Pegayaman).

Pemerintah atas, dalam hal ini instansi vertikal seperti kecamatan maupun dinas dinilai kurang responsif dan akomodatif dalam memahami karakteristik permasalahan lokal dibawahnya, yang pada akhirnya termasuk pula menghambat pengembangan multikulturalisme di tingkat lokal. Misalnya pengertian dalam penanganan kondisi darurat warga saat perayaan hari agama atau pengabaian potensi lokal di bidang kepariwisataan yang semata mata disublimkan pada kepentingan perijinan atau atas nama ketertiban.

"Suatu ketika kamu menerima kunjungan mahasiswa sekian ratus orang untuk berwisata edukasi terkait multikulturalisme. Padahal pihak travel dan penyelenggara sudah ijin dan mematuhi aturan pada pemerintah setempat. Namun mereka akhirnya tertolak oleh pihak kepolisna sektor (polsek) karena dianggap tidak ada tembusan disana. Sedangkan kami sebagai desa sifatnya hanya menerima. Kalau kami tidak menerima tentu saja salah. Padahal peserta ini adalah mahasiswa dan kaum terpelajar seperti dosen, dan mereka terteror oleh aparat karena dianggap tidak minta ijin. Saya mengatakan pada Camat ini bisa merusak reputasi Bali dan perlakuannya sungguh berbeda dengan desa tetangga seperti Git Git yang diterima dengan baik dan tidak ada yang mempermasalahkan. Ini yang kami bingung. Padahal Pegayaman punya potensi budaya luar biasa, terutama saat Maulid Nabi. Kami lebih terkenal di internet daripada promosi oleh pemerintah daerah setempat. Semua elemen kita selalu undang, baik Pak Camat sampai Gubernur namun tidak pernah dapat sambutan hangat dari mereka. Mereka selalu tidak hadir hanya kadang kalau jelang pemilu mereka selalu mau hadir. Kami dari sisi ini merasa dianak tirikan. Belum ada pengembangan soal pariwisata multikulturalisme di Pegayaman. Kabupaten seolah selalu tutup mata soal ini" (Wawancara Sekretaris Desa Pegayaman, Buleleng).

Berbeda dengan kondisi yang ada di Desa Dalung. Karakteristik desa Dalung memang multikultur, dimana dari suku, agama apa saja ada disini. Segala bentuk program diorientasikan untuk memberikan rasa keadilan karena terpulang pula dari tugas perbekel 
untuk mengayomi masyarakat. Tantangan untuk menyelesaikan masalah multikulturalisme, pemerintah desa Dalung sudah jauh lebih tanggap karena karakteristik SDM penunjang yang mencukupi. Hal ini seperti menangani perselisihan atau sengketa antar warga yang sifatnya multikultur sudah bisa diselesaikan di masing masing tingkat kepala urusan (Kaur). Begitu pula dengan perayaan keagamaan, perangkat desa berusaha terlibat di dalamnya.

Namun yang menjadi menarik, dari hasil wawancara dengan informan, justru tantangannya adalah tetap pemerintah atasan/vertikal, seperti kecamatan atau dinas, dimana seolah membiarkan pemerintah desa untuk menyelesaikan segala bentuk perselihian atau konflik maupun perilaku multikulturalisme yang selalu dinamis terjadi di masyarakat. Karena Dalung bertiplogi Kota maka wilayah ini dijadikan sasaran tempat tinggal pendatang. Sebagi besar yang mendiami Dalung adalah pendatang dari Sumba atau Flobamora. Hanay saja mereka datang dan menetap di Dalung bahkan untuk bekerja tanpa skill, pendidikan memadai. Mereka mau bekerja serabutan termasuk menerima pekerjaan yang beresiko sehingga desa seringkali kewalahan menyelsaikan persoalan perselisihan (perkelahian) diantara mereka termasuk membantu usaha pengiriman sekitar 2 hingga 3 mayat dikirim ke rumah asal mereka setiap saat.

Desa Dalung juga memberikan porsi pengembangan toleransi sangat tinggi karena karajter wilayah yang memiliki tempat tempat pendidikan, seperti PAUD, TK dan PT. Namun di sisi lain, wilayah Dalung hampir 128 hektarnya adalah wilayah perumahan pendatang dengan beragam etnik dan agama, sehingga aspek pengembangan multikulturalisme menjadi tantangan dan prioritas tersendiri bagi pengembangan desa. Dalung harus menerjemahkan sendiri, bagaimana agar kepentingan pengembangan pembangunan nya termasuk dalam pembangunan multikulturalisme bisa terjamin. Pada usaha ini, Dalung memiliki masterplan pengembangan Desa, dimana segala bentuk pengembangan kegiatan dan pembangunan infrstaruktur harus berdasar dan mengacu pada masterplan ini. Perumus dari masterplan ini ditetapkan melalui musyawarah desa dan penyusunnya juga dibuat oleh perbekel desa adat, Harapannya segala bentuk pengembangan pembangunan di Dalung tidak boleh parsial, meski kepala desanya bisa bergantu ganti namun prioritas yang ada dalam masterplan tetap terjaga dan terjamin. Sinergitas prioritas pembangunan antara regulasi Desa Adat yang menjamin adanya multikulturalisme di dalamnya maupun UU Desa yang lebih ke pengembangan pembangunan menyeluruh bisa berjalan beriringan. Harapannya adalah agar prinsip Tri Hita Karana dalam pembangunan di Dalung bisa terimplementasi dengan baik (Wawancara Perbekel Desa Dalung, Badung).

Dalam upaya memanajemen pembanguan multikulturalisme ini memang tidak bisa dilepaskan dari beragamnya permasalahan yang membelit dari faktor faktor kekuasaan yang ada di sekelilingnya. Namun diakui bahwa permasalahan justru kerap dari satu kelompok yang sama, dimana seringkali memunculkan friksi dan benturan atau gesekan dengan yang lain. Yang terpenting apabila program pembangunan beserta dana desa digunakan dengan pengawasan bersama maka gesekan ini bisa dihindari.

\section{KESIMPULAN}

Negara melakukan kontrol terhadap segala bentuk pembangunan terutama dalam pengembangan multikulturalisme di level desa hanya kosmetikal. Yang ditampilkan lebih pada pola instruktif. Di publik, mereka terkesan memberikan ruang kreatifitas bagi masingmasing desa, namun di sisi lain mereka masih memegang kendali yang sangat kuat terutama melalui kontrol pelaporan administrasi keuangan dengan beragam regulasi yang 
tumpang tindih. Kebijakan untuk membangun desa aturanya selalu berubah ubah. Kadang masih ada meja ini dan meja itu yang selalu tidak sama dan merepotkan.

Pemerintah atas, dalam hal ini instansi vertikal seperti kecamatan maupun dinas dinilai kurang responsif dan akomodatif dalam memahami karakteristik permasalahan lokal dibawahnya, yang pada akhirnya termasuk pula menghambat pengembangan multikulturalisme di tingkat lokal, termasuk pada potensi pengembangan kegiatan multikulturalisme.

\section{UCAPAN TERIMA KASIH}

Ucapan terimakasih ditujukan kepada Rektor Universitas Udayana dan Ketua LPPM Universitas Udayana karena penulisan artikel ini didasarkan dari penggalian data bersumber Hibah Unggulan Udayana Tahun Anggaran 2019. Penulis juga mengucapkan terimakasih kepada narasumber terkait riset ini

\section{DAFTAR RUJUKAN}

\section{Buku}

Al-Makassary, Ridwan (2007) "Multikulturalisme: Review Teoritis dan BeberapaCatatan kritis", dalam Hak Minoritas: Multikulturalisme dan Dilema Negara Bangsa, Ed. Mashudi Noor Salim et. al. Jakarta: Intereksi Foundation.

Ardhana, I Ketut, dkk (2011) Masyarakat Multikultural Bali; Tinjauan Sejarah, Migrasi dan Interaksi. Pustaka Larasan \& Jurusan Sejarah Fakultas Sastra Universitas Udayana.

Gutomo, Tomi (2008) Bermain Main dengan Kematian: Petani Jawa Tengah. Kanisius Yogyakarta.

Laclau, Ernesto (2010) Hegemony and Socialist Strategy: Towards a Radical Democratic Politics. Paperback.

Picard, Michel (1990) Bali: Cultural Tourism and Touristic Culture. Singapore: Archipelago Press.

Moleong, Lexy J. 2007. Metodologi Penelitian Kualitatif: Bandung: Rosdakarya.

\section{Jurnal}

Ahimsa-Putra, Heddy Shri (2007) Paradigma, Epistemologi, dan Etnografi dalam. Antropologi. Makalah disampaikan dalam seminar di UNAIR Surabaya.

Callahan, Ewa (2005) Interface design and culture. https://doi.org/10.1002/aris.1440390114.

Goodenough, Ward. H. (1967) Right and Wrong in Human Evolution. https://doi.org/10.1111/j.1467-9744.1967.tb01096.x

Gottowik, Volker (2010) Transnational, Translocal, Transcultural: Some Remarks on the Relations between Hindu-Balinese and Ethnic Chinese in Bali. Source: Sojourn: Journal of Social Issues in Southeast Asia, Vol. 25, No. 2 (October 2010), pp. 178212. Published by: ISEAS - Yusof Ishak Institute. Stable URL: https://www.jstor.org/stable/41057096. Accessed: 04-02-2019 09:58 UTC.

Kwon, Ronald (2018) Multiculturalism in the Age of Immigration: Diversity, Cultural Rights, and Potential Conflict. https://escholarship.org/uc/item/1c2775j.

Pageh, I Made. Dkk. 2014. Analisis Faktor Integratif Nyama Bali-Nyama Selam. DOI: 10.23887/jish-undiksha.v2i2.2178.

Parker, Lyn (2017) Intersections of Gender/Sex, Multiculturalism and Religion: Young Muslim Minority Women in Contemporary Bali. Asian Studies Review, 41:3, 441458, DOI: $10.1080 / 10357823.2017 .1332004$. 
Selenica. Ervjola (2018) Education for whom? Engineering multiculturalism and liberal peace in post-conflict Kosovo, Southeast European and Black Sea Studies, DOI: 10.1080/14683857.2018.1474583 Southeast Asian Studies, 48 (1), February 2017.

Tamatea, Laurence (2006) Gandhian education in Bali: globalisations and cultural diversity in a time of fundamentalisms. ISSN 0305-7925 (print)/ISSN 1469-3623. British Association for International and Comparative Education, DOI: 10.1080/03057920600741248.

\section{Surat Kabar}

Bali Express 2 Mei 2018 diakses pada https://baliexpress.jawapos.com/read/2018/ 05/02/69890/soal-rastra

pegayaman-disalahkan-dinsos-perbekel-ngotot-tak-salah, pada 22 September 2019. 